\title{
Fur, Gold, and Settlement: The Building Blocks of Range Management in British Columbia
}

\section{By Alfred Bawtree and Lisa Zabek}

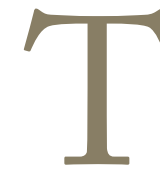

he 2012 annual meeting of the Society for Range Management is a partnership of the Idaho and Pacific Northwest (PNW) Sections representing a combined area of about 1.3 million square miles, or one-third the size of Canada or the United States. Together with the natural resources, the meeting theme of history, culture, and tradition produces the building blocks of our rangelands and their management.

British Columbia is Canada's most westerly and third largest province. It occupies about $944,735 \mathrm{~km}^{2}(364,764$ square miles) between the 49th and 60th parallels. The landscape is dominated by rugged mountain belts, river valleys, and plateaus and by plains in the northeastern corner. Volcanism and repeated continental glaciation have formed the skeleton of today's landscapes. Lava flows and cliffs, glacial drift, scoured surfaces, steep rocky slopes, and colluvial, fluvial, and aeolian deposits all form components of the provincial landscape. This variation is reflected in ranges of climate, soils, plant, and animal resources. Climates span from cool, moist, and mountainous to marine, Mediterraneanlike, semiarid, alpine, and subarctic. Soils utilized for crop and livestock production range from moderately well-developed mineral soils to fully saturated organic soils and those containing permafrost near the soil surface. Soil textures range from coarse and well-drained sands or gravels to dark, fertile loams. Ranching and rangeland management have a long history in the province, originating with European discovery of "riches" within the wilderness and evolving to recognition and management for multiple use.

\section{Furs and Gold}

Furs were integral to development of trade and transportation corridors in British Columbia. Furs had high value, and early explorers representing fur-trade companies trekked across the seemingly limitless spaces and wilderness to facilitate trade with First Nations peoples. Alexander Mackenzie was the first European to cross North America north of Mexico, reaching the Pacific Coast at Bella Coola in 1793. In 1805 Simon Fraser followed Mackenzie into central British Columbia, building forts to facilitate trade and subsequently journeying down the Fraser River to its mouth near Vancouver in 1808. David Thompson crossed the Rockies into southeastern British Columbia in 1807 and later followed the Columbia River from its headwaters in British Columbia to its mouth near Astoria, Oregon. These three men were part of the North West Company (1779-1821), a fur trading enterprise based out of Montreal. It competed with the Hudson's Bay Company for the lucrative western fur supply and was eventually forced to merge with the Hudson's Bay Company after several decades of rivalry and strife. The forts were later transformed from simple trading posts to larger settlements following a decree that required them to be self-sufficient and produce a surplus of foods for trade.

The Hudson's Bay Company used an extensive system of boats and horse trails to carry furs from central British Columbia to the mouth of the Columbia River. In 1846 the boundary between British Columbia and the United States was established at the 49th parallel. This severed the horse trail by which furs were carried to the Columbia River. The Cayuse War in American territory and heavy customs duties forced the Hudson's Bay Company to find new routes to access the Pacific Ocean. These later became trails for gold miners and settlers.

The discovery of gold in the Fraser River brought worldwide attention to what is now British Columbia. It spurred an influx of people from the east, the United States, and many other countries. For example, the population of Victoria grew from fewer than 300 to as many as 6,000 in 1858. In 1858 British Columbia became a British colony with James 
Douglas as governor. The birth of British Columbia was an essential outcome of the population explosion brought on by the discovery of gold. The British government took on a responsibility for law, order, and support for the population. Along with the population explosion, there was an acute need to feed the miners working in the upper reaches of the Fraser River.

The rugged Coast Mountains presented an awe-inspiring barrier to travel. The Fraser River cut through the mountains, but it was too swift and treacherous for boat travel. Trails were built allowing horses to carry goods to miners working further up the Fraser River. By 1863 a wagon road through the Coast Mountains connected with the earlier Cariboo Trail leading from Clinton to the Cariboo goldfields. The old Hudson's Bay horse trail leading through the Okanagan Valley and eastern Washington became a cattle trail as thousands of cattle, horses, and sheep were driven over it to the mines on the upper Fraser River and its tributaries. Animals moved from the United States through the Okanagan Valley, entering British Columbia at Osoyoos, traveling along the western shore of Lake Okanagan and following the Thompson and Bonaparte Rivers into the Cariboo. The trail is now shown on Washington road maps as the "Cariboo Cattle Trail 1859-1868". The native grasslands of the Interior Plateau provided excellent forage. Drovers from the United States made heavy use of these rangelands as they slowly drove their livestock toward the mines. About 22,000 head of cattle entered British Columbia between 1858 and 1868. Records indicate that cattle purchased for $\$ 10$ a head could be sold in the goldfields for $\$ 50$ a head. Forage for the animals was free and plentiful, and soon enterprising individuals were raising cattle and horses within British Columbia. Gold rushes are volatile, and so too are the markets they provide. By the late 1860s the cattle market was drying up, and ranchers in the British Columbia interior needed to look for markets elsewhere.

\section{Settlement Then and Now}

First Nations peoples have inhabited what is now called British Columbia for thousands of years. The influx of European settlers impacted First Nations in varied ways, from the introduction of the horse and availability of manufactured trade goods to epidemics and land preemption. Today there are over 200 distinct First Nations communities, seven major language groups, and 30 dialects and a strong Metis culture and presence. ${ }^{1}$ This diversity is reflected in distinct and rich histories, social traditions, cultures, and art.

Victoria, British Columbia's capital, was one of the first settlements. In 1849 the Hudson's Bay Company headquartered there after the boundary between British Columbia and the United States was established. However, after the completion of the trans-Canada, Canadian Pacific Railway (CPR) in 1885, Vancouver replaced Victoria as the major center.

Settlement was slower in the interior of the province. During the gold rush small settlements grew up around the roadhouses on the wagon roads, serving the miners traveling to and from the goldfields. Some, such as Lytton, Clinton, and Williams Lake, still exist as population and service centers, but others have virtually disappeared. Barkerville was the terminus of the Cariboo Wagon Road and once the largest city on the mainland, with a peak population of about 5,000 in the mid-1860s. It is now a historic site and tourist destination.

The completion of the CPR across Canada contributed to settlement all along its corridor, providing an efficient means for transportation and distribution of goods. Before its completion, interior cattle had to be herded over rough trails to markets at the gold fields or on the west coast. The railways greatly reduced the time and effort required for cattle to reach market. They also enabled settlers to obtain goods more cheaply for improvement of their farms and ranches.

Ranching still retains importance in many areas of the province and is readily apparent in the grassland/grasslandforest interface zones of the Kamloops area, south to Merritt, and north to Clinton, Williams Lake, and Quesnel. Several small communities in the Chilcotin area west of Williams Lake serve a permanent ranching population, plus a forestry and recreation clientele. However, ranching interests can be found in most corners of the province. Along with other resource management sectors such as forestry, fishing, mining, and recreation, the ranching sector forms an integral component of local economies in the northwest, northeast, and southeast regions.

\section{Ranching}

Some Hudson's Bay Company forts kept cattle for their own use as early as 1840. They had large numbers of horses for transporting furs, trade goods, and supplies. When the gold rush spread up the Fraser River into the interior, enterprising individuals acquired land and began raising beef cattle and horses for the miners. After the initial Fraser Canyon gold rush a series of subsequent rushes ensued, the most famous of which was the Cariboo gold rush. The mines provided a market for beef, but as they petered out so too did the market. Beef prices dropped from 35 to 25 cents per pound, and ranges were becoming overstocked and overgrazed. Severe winters in the late 1800 s temporarily reduced cattle numbers. In the Nicola Valley about 25 percent of the cattle died from 1879 to 1880 . This made ranchers aware that hay production and winter feeding were necessary.

$\mathrm{CPR}$ construction through the British Columbia interior began in 1880, providing a market for beef until its completion in 1885, after which the railway opened access to the growing markets on the coast and beyond. By 1900 fencing was underway to protect hay fields and winter ranges from summer grazing. Ranchers were also noting that grasslands were becoming less productive. Up to this time livestock grazing had been restricted to the grasslands, and although winter grazing was rapidly coming to an end, the native 
bunchgrasses were suffering from overstocking and seasonlong grazing. Meadows were being converted to hay lands, and ditch irrigation was practiced on cultivated uplands. Many ranchers believed that one good rain would bring the grass back to its former productivity. Other ranchers were wondering how or if the range could recuperate and were turning to government for answers.

The First World War (1914-18) had far-reaching effects on British Columbia ranches and their rangelands. Most soldiers were between 18 and 45. Labor to herd cattle and produce hay became hard to find. At the same time governments were urging ranchers to produce more beef and horses for shipment overseas. Livestock numbers increased from about 100,000 in 1915 to 190,000 in 1917, and rangelands suffered. After the war, British Columbia passed the Grazing Act, which gave the British Columbia Forest Service authority to control livestock grazing on public lands. One person was employed to administer the Act and Regulations throughout the ranching country.

The Second World War (1939-45), like the First World War, caused labor shortages and placed pressure on ranchers to increase beef production. Despite the passage of the Grazing Act in 1919, little was done toward controlling livestock use of the range. However, ranchers were increasingly aware of the need to conserve the range resource. They started to use forested range and took steps to improve livestock distribution through fencing, trail construction, and water developments. It was not until after the war that serious attempts were made to initiate scientific range management.

Horses also contributed to the overgrazed range condition. They had spread into British Columbia by about 1730 and were widely used and valued by First Nations peoples before arrival of the fur traders. With the fur trade, horse populations expanded. Brigades with 200 to 300 or more horses traveled the trade routes, stopping at established camp sites, using the forage and water resources. By 1848, reports indicate 500 to 600 head at Fort Kamloops, an exchange point in the interior for horses carrying supplies up or furs down the Okanagan. ${ }^{2}$ These same travel routes were the ones later used by drovers moving animals to the gold fields. The animals often moved very slowly and sometimes remained in one area over the winter. As early as 1873, one traveler reported the range in the vicinity of Ashcroft to be little better than a sand and gravel pit, and cattle had eaten off all the grass within three or four miles of the road and it had been replaced by sage. ${ }^{3}$

Feral horses were numerous on the range early in the twentieth century. Horses grazed all year, contributing to the overgrazed condition. Between 1918 and 1928 about 4,960 horses were removed from Crown range, of which 1,400 were shipped to Russia. ${ }^{4}$ By the middle of the twentieth century most of the horses had been removed from the range, and it was starting to improve. However, today feral horses have become a concern in some locales.
Grasshoppers and drought also contributed to the poor range condition. Grasshopper control areas and poisoning took place in the 1930s following repeated outbreaks on many grassland sites. Drought conditions in the early 1930s contributed to low forage production and slowed attempts to improve range condition.

Attitudes in the early twentieth century contributed to a lack of concern for range condition. The provincial government believed there were great opportunities for increasing the cattle industry by utilizing unused range on the "vast natural stock ranges." It was acknowledged that grassland range was limited, but the belief was that the forested area provided excellent natural forage for cattle. ${ }^{5}$ Unfortunately initial attempts to use forested range resulted in the poisoning of many cattle by timber milk vetch (Astragalus miser). Poisoning has been greatly reduced through awareness, improved range management practices, and improved range condition.' Grasslands on the forest edge were usually heavily grazed before cattle could be enticed to eat pinegrass (Calamagrostis rubescens) and other plants under the tree canopy.

In contrast, today, forest land is particularly important as a provincial Crown range resource. In many areas of the province, range management has evolved to follow an elevation gradient. Animals are typically wintered at lower elevations near the ranch and move to the higher-elevation, forested Crown range in late spring and summer. However, both the grassland and forested range resources are being impacted by a multitude of factors. Fire suppression has resulted in forest ingrowth in open forests and encroachment on grasslands. Drought, wildfire, and mountain pine beetle epidemics all affect the condition and use of British Columbia rangelands.

Aside from the few sheep brought to Vancouver Island prior to 1860 by the Hudson's Bay Company, sheep arrived on the heels of the cattle drovers during the gold rush. Records show 1,371 animals crossed the border at Osoyoos between 1861 and 1862, and 9,000 head were imported by the British Columbia Cattle Company in $1891 .^{6}$ A rapid rise in numbers occurred in the 1920s as sheep ranchers discovered the value of alpine range for raising lambs. Large flocks were driven up to alpine range where they grazed for about three months. Sheep were the first domestic animals to graze these high-elevation ranges. This practice continued until the 1950s and 1960s when most sheep ranching ceased or was scaled back because of labor and travel costs. Farm flocks are presently scattered throughout the farming areas of British Columbia. Beginning in the mid-1980s foresters and sheep ranchers used sheep to harvest forage and reduce herbage competition on young plantations. The program

\footnotetext{
'Personal communication, R. Haywood-Farmer, third-generation rancher in the Savona area of the southern interior of British Columbia and member of the British Columbia Cattlemen's Association, November 28, 2010.
} 


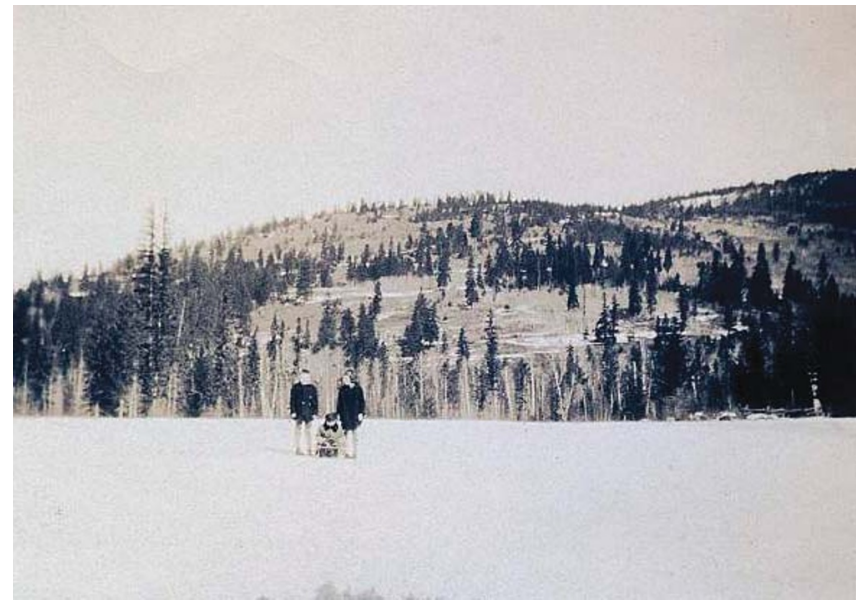

Late winter (circa 1931), range resources, southern interior of British Columbia. Photo courtesy of the Bawtree family.

was discontinued because of travel and herding costs and predator losses.

\section{Range Science}

By 1935 ranchers had successfully petitioned the Canadian government to open a range experiment station at Kamloops, and the first studies of plant community, range condition, and carrying capacity were initiated. The substation closed in 1940 following the start of the Second World War and did not reopen until 1947, then as a Dominion Experimental Station with an expanded research program and staff. This coincided with an increase in the number of staff hired by the Forest Service to administer the grazing act. Close cooperation between federal research staff and provincial range administrative staff brought better range management and improvement. The inauguration of the SRM in 1948 saw several federal and provincial employees as well as some ranchers become members. In 1949 Oregon, Washington, and British Columbia members united to form the Pacific Northwest (PNW) Section. In 1981 the British Columbia Chapter of the PNW Section was formed with rancher Bill Stewart as president.

The theme of SRM's 2012 meeting relates to history, culture, and tradition. First Nations inhabitation before European settlement, the fur trade, gold rushes, railways, and wars all have directly and indirectly shaped British Columbia's rangelands and grazing management. Ninetyfour percent of British Columbia is publicly owned. The ranching sector relies on both private and public grazing lands, the latter administered by natural resource ministries of the provincial government. A mix of private land, grazing leases, licenses, and permits make up the grazing resources accessed by ranchers. The grazing resource extends well beyond the grasslands originally exploited by the first drovers, to encompass the forests and forest grassland interface. Livestock grazing overlaps with other uses on the land such as timber management, mining, recreation, guiding, community

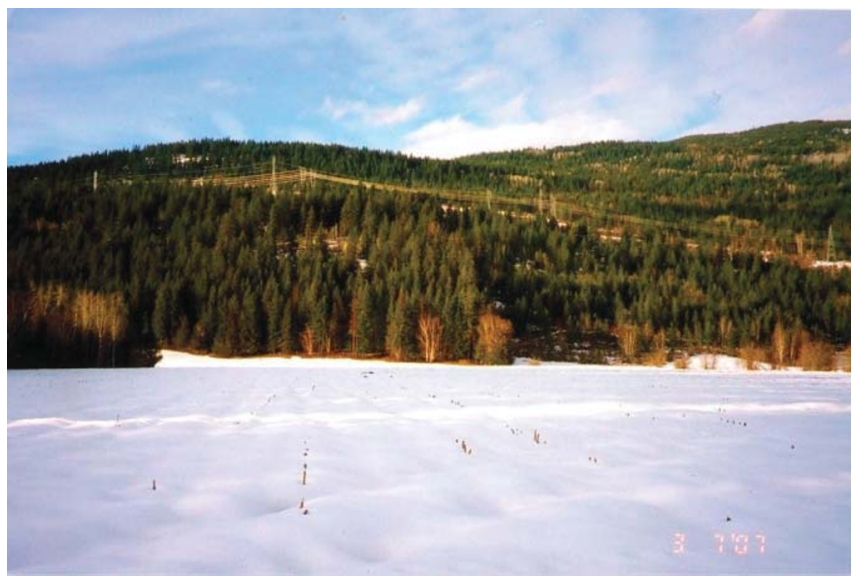

Same location (circa 2007), range resources, southern interior of British Columbia. Photo courtesy of the Bawtree family.

watersheds, and wildlife use. As this present becomes the past, it too will form a component of future assessments of rangeland condition and management.

\section{Acknowledgments}

This manuscript benefited greatly from reviews and comments from Lavona Liggins, Lynne Breese, and Francis Njenga and review and proofing by Nancy Portman.

\section{References}

1. Aboriginal Tourism Association of BC. Available at: http://www.aboriginalbc.com. Accessed 23 January 2011.

2. Howay, F. W., and E. O. S. Scholefield. 1914. British Columbia from the Earliest Times to the Present. Volume II. Vancouver, BC, Canada: S. J. Clarke Publishing Company. 727 p.

3. Balf, M. 1978. Bunch-grass beef ranching in the Kamloops district. Kamloops, BC, Canada: Kamloops Museum. 18 p.

4. Casorso, V. 1996. When Okanagan wild horses were sold to Russia. In: Okanagan history: The 60th report of the Okanagan Historical Society. Salmon Arm, BC, Canada: Hucal Printing. p. $122-125$.

5. Chase Tribune. September 19, 1913.

6. Vrooman, C. W. 1941. A history of ranching in British Columbia. Economic Annalist 11(2):20-23.

\section{Additional Sources}

Akrigg, G. P. C., and H. R. Akrigg. 1977. British Columbia Chronicle 1847-1871. Gold and colonists. Vancouver, BC, Canada: Discovery Press. 439 p.

British Columbia Cattlemen's Association. 1998. Rangeland handbook for BC. C. W. Campbell and A. H. Bawtree [EDs.]. Kamloops, BC, Canada: BCCA. 203 p.

British Columbia Ministry of Environment. 1978. The soil landscapes of British Columbia. K. W. G. Valentine, P. N. Sprout, T. E. Baker, and L. M. Lavkulich [EDs.]. Victoria, BC, Canada: BC Ministry of Environment, Resource Analysis Branch. 197 p.

Cox, D. 2004. Ranching now, then, and way back when. Penticton, BC, Canada: Skookum Publications. 304 p. 
Milroy, J. E., And A. Mclean. 1980. History of range administration and research in British Columbia. Rangelands 2:56-59.

Steves, J., And A. Mclean. 1989. History of the cattle industry in British Columbia. Rangelands 11:62-64.

Wade, M. S., and E. A. Eastick [Researched, Annotated, And IndeXed]. 1979. The Cariboo Road. Victoria, BC, Canada: Haunted Bookshop.

Webber, J. 1999. A rich and fruitful land: the history of the valleys of the Okanagan, Similkameen and Shuswap. Madeira Park, BC, Canada: Harbour Publishing. 239 p.
Woolliams, N. G. 1979. Cattle ranch: the story of the Douglas Lake Cattle Company. Vancouver, BC, Canada: Douglas and McIntyre. 266 p.

Authors are Range Management Specialist (retired), British Columbia Ministry of Forests, British Columbia Ministry of Agriculture and SRM member for more than 55 years, Celista, British Columbia (Bawtree); and Agroforestry Specialist, British Columbia Ministry of Agriculture, Kamloops, British Columbia, Lisa.Zabek@gov.bc.ca (Zabek).

\section{Winter Dance-2012}

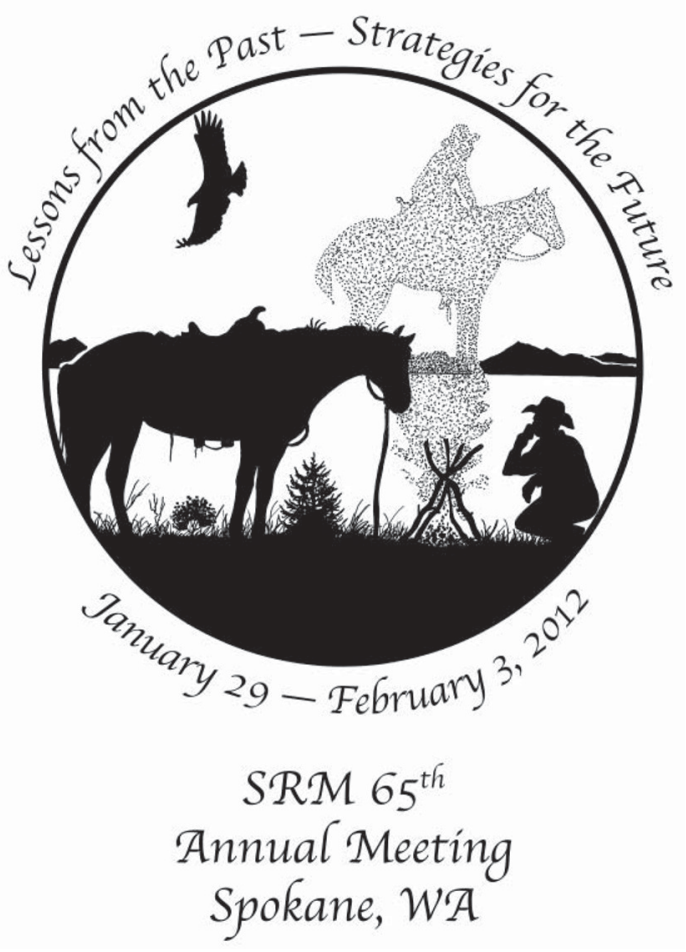

